\title{
RELATIONSHIP BETWEEN CRITICAL THINKING AND CREATIVE THINKING THROUGH ZOOM MEETING ON SCIENCE LEARNING IN ELEMENTARY SCHOOL
}

Submitted:

3 November 2021

Accepted:

5 Desember 2021

Published:

31 Januari 2022

\author{
Meirza Nanda Faradita1, Deni Adi Putra ${ }^{2}$, Muhammad \\ Nuruddin $^{3}$ \\ meirzananda@fkip.um-surabaya.ac.id ${ }^{1}$,deni adiputra@fkip.um- \\ surabaya. ac.id ${ }^{2}$, rudin.moxer@gmail.com ${ }^{3}$ \\ Universitas Muhammadiyah Surabaya ${ }^{1,2}$, Universitas Hasyim \\ Asy'ari Tebuireng Jombang ${ }^{3}$ \\ *Corresponding Author
}

\begin{abstract}
Humans are social creatures who need to develop themselves in facing life in society. To understand something, a person's way of thinking is influenced by knowledge, the ability to see, and the ability to create a strategy in thinking. One of them is in the education. Based on observations, it is shown that the learning carried out by the teacher when teaching is less varied so that it seems monotonous and the questions asked by the teacher are not in-depth only in the cognitive domains of C1 and C2. Lack of direct application (practice) when learning and the work made by students is less innovative. Through the zoom application, students can also do online learning. This study aims to determine the relationship between students' critical and creative thinking through the Zoom application and science learning outcomes. The type of research used in this research is quantitative correlational type. The subjects of this study were fifth grade students of SD Muhammadiyah 8 Surabaya. From the research that has been carried out, the results obtained are: (1) There is a relationship between critical thinking through the Zoom application and science learning outcomes, because the value of Sig. $<0.05(0.008$ $<0.05)$; (2) There is a relationship between creative thinking through the Zoom application and science learning outcomes, because the value of Sig. $<0.05$ (0.006 < 0.05); (3) There is a relationship between critical and creative thinking through the Zoom application with science learning outcomes because of the value of Sig. $<0.05(0.009<$ $0.05)$.
\end{abstract}

Keywords: Critical Thinking; Creative Thinking; Zoom Meetings; IPA

\section{INTRODUCTION}

Humans are social creatures who need to develop themselves in dealing with life in society. Along with the development of time and era, humans are required to take an understanding of something that has been experienced in life(Kuntarto, Sofwan, \& Mulyani, 2021). To understand something, a person's way of thinking is influenced by knowledge, 
ability to see, and ability to create a strategy in thinking. One of them is through education. Education directs humans to develop basic potentials so that they become real.

Education according to the National Education System Law No. 20 of 2003 (Afiani \& Faradita, 2021) is a learning atmosphere that has been consciously planned in the learning process to develop students' potential to have religious-spiritual strength, personality, intelligence, and skills. According to Ki Hajar Dewantara (Neolaka, 2017) Education is an effort to cultivate children's ethics, reason, and body, to increase perfection to bring children to live in harmony with nature and society. Education is an important role for the community as a learning process to gain knowledge as a provision for the future. According to R. Gagne (Susanto \& Retnawati, 2017), learning is a process of behavior change in which learning and teaching are two concepts that cannot be separated into one unified interaction activity when conducting direct learning.

According to Bigge (Nuruddin, 2018) in fact, there are two poles of learning in education, namely tabula rasa and constructivism. According to the tabula rasa reference, students are likened to a white paper that the teacher can write anything on or like an empty container that the teacher can fill in anything. This opinion is as if students are passive and have limitations in learning. According to constructivism, each person learns to build his knowledge. So students are active and can continue to improve themselves under certain conditions.

According to Piaget (Son, 2018) argued that every individual can build his knowledge since childhood. Building knowledge is done through the process of mixing and facilitating existing designs. The implication of the constructivism view in schools is that knowledge cannot be transferred completely from the teacher's mind to students, but students can build their knowledge through their experiences.

According to Piaget (Samatowa, 2016) revealed that learning science is a process that requires active support from students so that the position of the teacher becomes a supporter and provider of student learning. Science is a way to observe natural phenomena that is investigative/analytical, thorough, careful, and linking one phenomenon to another, therefore all of which form a new point of view regarding the object that has been observed. Science learning provides opportunities for children to develop their thinking skills in explaining a problem (critical thinking). 
According to Fisher (Sulistiani \& Masrukan, 2017) argued that learning to think critically means students who can reason until they can test their knowledge, assess skills, ideas, and consider arguments before reaching a balanced justification. Not only critical thinking but in science learning students are also required to have creative thinking. According to Cropley, creative thinking is thinking to get a special idea or concept that is discovery and new.

Based on the results of the researcher's observations, it shows that in science learning for the fifth grade of SD Muhammadiyah 8 Surabaya the score that must be taken is 75 . From 50 students only 20 students can reach the KKM, while the rest still have not reached the KKM. From this assessment, it can be seen that students' learning experience is still lacking and students have not been able to find alternative problem-solving. Learning is carried out by the teacher in teaching is less varied so that it seems monotonous and the questions asked by the teacher are deep less and limited to the cognitive domains of $\mathrm{C} 1$ and C2. Lack of direct application (practice) in learning and the work made by students is less innovative.

The description above explains that students' critical and creative thinking skills play an important role in achieving learning outcomes. For this reason, the relationship between critical and creative thinking skills makes students able to solve a problem, find alternative solutions and play an active role in producing innovative work.

Based on previous research, which has been done (Faradita, 2018) with the title "Application of CLIS Learning by Using Simple Teaching Aids to Improve Problem Solving Thinking Skills" explained that student responses in learning science by applying CLIS learning using simple teaching aids can improve problem-solving thinking skills and improve student learning outcomes completeness both process and product. There are also previous studies that have been done(Neka, Marhaeni, \& Suastra, 2015) entitled "The Influence of Environmental-Based Guided Inquiry Learning Model on Creative Thinking Skills and Mastery of Science Concepts Class V SD Gugus VIII Abang Subdistrict" explained that the guided inquiry learning model in the science learning process can provide opportunities for students to actively participate in the learning process. The guided inquiry learning model based on the environment gives better results than the direct learning model.

The purpose of this study was to determine how much the relation between students' critical and creative thinking skills. Carrying out further research, the researcher wrote the 
title of this research on "Relation between Critical and Creative Thinking through the Zoom application and Science Learning Outcomes in the fifth-grade Students of SD Muhammadiyah 8 Surabaya".

\section{METHODS}

This research used correlational quantitative research, with the research subjects being the fifth-grade students of SD Muhammadiyah 8 Surabaya, totaling 50 students. According to (Sugiyono, 2019) research variables are objects or activities that have various kinds that have been determined by the researcher to be understood and then draw conclusions. The variables in this study can be divided into two, namely independent variable $\left(\mathrm{X}_{1}\right.$ and $\left.\mathrm{X}_{2}\right)$ is critical and creative thinking and the dependent variable $(\mathrm{Y})$ is science learning outcomes.

The data collection instruments used in this study were test sheets and Likert scale questionnaire sheets containing positive statements.

Table 1. Critical Thinking Instrument Grid

\begin{tabular}{|c|c|c|c|}
\hline Variables & Indicator & $\begin{array}{l}\text { Number } \\
\text { Item }\end{array}$ & $\begin{array}{c}\text { Number } \\
\text { of }\end{array}$ \\
\hline Critical & 1. Give a simple explanation. & $1,2,3$ & 3 \\
\hline Thinking & 2. Build basic skills. & $4,5,6$ & 3 \\
\hline & 3. Conclusion & $7,8,9,10$ & 4 \\
\hline & 4. Provide further explanation. & $11,12,13$ & 3 \\
\hline & $\begin{array}{c}\text { 5. Measure strategy and tactics. } \\
\text { Total }\end{array}$ & 14.15 & $\begin{array}{c}2 \\
15\end{array}$ \\
\hline
\end{tabular}

Source: Adoption of positive statements (Ennis, 2017)

Table 2. Grid of Creative Thinking Instruments

\begin{tabular}{|c|c|c|c|}
\hline Variables & Indicator & $\begin{array}{l}\text { Number } \\
\text { Item }\end{array}$ & $\begin{array}{c}\text { Number } \\
\text { of }\end{array}$ \\
\hline Creative & 1. A great curiosity. & 1,2 & 2 \\
\hline \multirow[t]{7}{*}{ Thinking } & $\begin{array}{l}\text { 2. Gives lots of ideas and } \\
\text { suggestions. }\end{array}$ & 3,4 & 2 \\
\hline & $\begin{array}{l}\text { 3. Able to propose thoughts and ideas } \\
\text { that are different from others. }\end{array}$ & $5,6,7$ & 3 \\
\hline & 4. Strong imagination & 8,9 & 2 \\
\hline & 5. Can work alone & 10,11 & 2 \\
\hline & 6. Give explanation & 12,13 & 2 \\
\hline & 7. Try new things & 14,15 & 2 \\
\hline & Total & & 15 \\
\hline
\end{tabular}

Source: Adopt positive statement (Wulandari, 2014)

For collecting technique data using several statistical tests. Validity test is used to show the level of validity of an instrument (Arikunto, 2010). 
An instrument can be said to be valid if the calculated $r$ value is greater than $r$ table. The formula that will be used to process, test or analyze data using SPSS 24 and Excel tools is as follows.

$$
r_{x y}=\frac{n(\Sigma X Y)-(\Sigma X) \cdot(\Sigma Y)}{\sqrt{\left\{n \cdot \Sigma X^{2}-(\Sigma X)^{2}\right\} \cdot\left\{n \Sigma Y^{2}-(\Sigma Y)^{2}\right\}}}
$$

Description:

$$
\begin{array}{ll}
r_{x y} & =\text { Correlation coefficient } \\
\mathrm{N} & =\text { Number of samples } \\
\mathrm{X} & =\text { Score of independent variables } \\
\mathrm{Y} & =\text { Score of dependent variable } \\
\text { Source: } & \text { (Sugiyono, 2016) }
\end{array}
$$

The calculation of the reliability test shows the level of reliability of something. The questionnaire is declared reliable if it has a Cronbach Alpha greater than $\mathrm{r}$ table. The study was analyzed using the formula Cronbach Alpha using the SPSS 24 program.

$$
r_{11}=\left[\frac{k}{k-1}\right][1
$$

Description:

$\mathrm{r}_{11}$ : instrument reliability

$\mathrm{k}:$ number of questions

$\sigma^{2}:$ sum of variance squared for each question item

$\sigma_{1}^{2:}$ quadratic variance in total

Source: (Sugiyono, 2019)

To test the research hypothesis, simple and multiple regression analysis tests were carried out with the help of SPSS 24.0 for Windows.

\section{RESULTS}

The results of the questionnaire instrument test were tested with validity and reliability tests. According to (Susanto \& Retnawati, 2017) The validity test is said to be valid if $r_{\text {count }}>r_{\text {table }}$, while the reliability test is said to be reliable if Cronbach's alpha $>r_{\text {table }}$. There are 2 questionnaires that have been tested, namely the critical and creative thinking questionnaire with a total of 15 questions.

According to (Antari, Wiarta, \& Putra, 2017) The normality test conducted in the classroom is the Kolmogrov Smirnov normality test to test critical and creative thinking questions to get a significance value of Asymp.Sig (2-tailed) of 0.200 greater than 
0.05 . So it can be said that the data that has been tested is normally distributed because the significance value or Sig. $>0.05$.

According to (Kusuma \& Khoirunnisa, 2018) the homogeneity test was carried out to find out if the test instrument given to the class was the same or homogeneous. The output results are known that the significance value (Sig.) of the test variable given is 0.356. Because of the value of Sig. $0.356>0.005$, so it can be concluded that the tests conducted in class are the same or homogeneous, because the significance value or Sig. > 0.05 .

According to (Komalasari, 2012) the linearity test was carried out to determine whether the relationship between the independent variable and the dependent variable was linear. The linearity test is done by looking at the Deviation from linearity value. The output results are known that the significance (Sig.) of the test variable given is 0.702 . Because of the value of Sig. $0.702>0.005$, so it can be concluded that the tests conducted in class are linear. Hypothesis test using simple and multiple regression analysis test. According to (Komalasari, 2012) Simple regression analysis test is an analysis that involves one independent variable and one dependent variable. This test is used to measure the magnitude of the relationship between the independent variable and the dependent variable.

Table 3. Simple Linear Regression Critical Thinking Ability Through Zoom Meeting Application on Science Learning Outcomes

\begin{tabular}{|c|c|c|c|c|c|c|}
\hline \multicolumn{7}{|c|}{ Coefficients $^{\mathbf{a}}$} \\
\hline \multirow{3}{*}{ Model } & & Unstanc & ized & Standardized & \multirow{3}{*}{$\mathrm{T}$} & \multirow{3}{*}{ Sig. } \\
\hline & & Coeffici & & Coefficients & & \\
\hline & & B & $\begin{array}{l}\text { Std. } \\
\text { Error }\end{array}$ & Beta & & \\
\hline \multirow{2}{*}{1} & (Constant) & 53,592 & 17,493 & & 3,064 & 0,004 \\
\hline & $\begin{array}{l}\text { Critical } \\
\text { thinking }\end{array}$ & 0,705 & 0,396 & 0,249 & 1,780 & 0,008 \\
\hline
\end{tabular}

a. Dependent Variable: learning outcomes

Source: SPSS Calculation Version 24

Based on the output above, it is known that the significance value (Sig.) of 0.008 is smaller than < probability of 0.05 . It can be concluded that $H_{0}$ is rejected and $H_{a}$ 
accepted, which means that "There is a relationship between critical thinking through the Zoom application and science learning outcomes".

Table 4. Simple Linear Regression Creative Thinking Through the Zoom Application on Science Learning Outcomes

\begin{tabular}{|c|c|c|c|c|c|c|}
\hline \multicolumn{7}{|c|}{ Coefficients $^{\mathrm{a}}$} \\
\hline & \multirow{2}{*}{ Model } & \multicolumn{2}{|c|}{$\begin{array}{l}\text { Unstandardized } \\
\text { Coefficients }\end{array}$} & \multirow{2}{*}{$\begin{array}{c}\begin{array}{c}\text { Standardized } \\
\text { Coefficients }\end{array} \\
\text { Beta }\end{array}$} & \multirow{2}{*}{$\mathrm{T}$} & \multirow{2}{*}{ Sig. } \\
\hline & & B & $\begin{array}{l}\text { Std. } \\
\text { Error }\end{array}$ & & & \\
\hline \multirow{2}{*}{1} & (Constant) & 53,696 & 17,556 & & 3,058 & 0,004 \\
\hline & Creative thinking & 0,540 & 0,393 & 0,194 & 1,372 & 0,006 \\
\hline
\end{tabular}

a. Dependent Variable: learning outcomes

Source: SPSS Calculation Version 24

Based on the output above, it is known that the significance value (Sig.) of 0.006 is smaller than < probability of 0.05 . It can be concluded that $H_{0}$ is rejected and $H_{a}$ accepted, which means that "There is a relationship between creative thinking through the Zoom application and science learning outcomes".

Table 5. Double Regression Table for Critical and Creative Thinking Through the Zoom Application with Learning Outcomes

\begin{tabular}{|c|c|c|c|c|c|c|}
\hline \multicolumn{7}{|c|}{ Coefficients $^{\mathrm{a}}$} \\
\hline & \multirow{2}{*}{ Model } & \multicolumn{2}{|c|}{$\begin{array}{l}\text { Unstandardized } \\
\text { Coefficients }\end{array}$} & \multirow{2}{*}{$\begin{array}{c}\begin{array}{c}\text { Standardized } \\
\text { Coefficients }\end{array} \\
\text { Beta }\end{array}$} & \multirow{2}{*}{$\mathrm{T}$} & \multirow{2}{*}{ Sig. } \\
\hline & & B & $\begin{array}{l}\text { Std. } \\
\text { Error }\end{array}$ & & & \\
\hline \multirow{3}{*}{1} & (Constant) & 49,247 & 17,504 & & 2,814 & 0,007 \\
\hline & $\begin{array}{l}\text { Critical thinking } \\
\text { (X1) }\end{array}$ & 0,888 & 0,249 & 0,760 & 3,567 & 0,006 \\
\hline & $\begin{array}{c}\text { Creative } \\
\text { thinking }(\mathrm{X} 2)\end{array}$ & 0,482 & 0,151 & 0,460 & 3190,000 & 0,003 \\
\hline \multicolumn{7}{|c|}{ a. Dependent Variable: Hasil Belajar (Y) } \\
\hline
\end{tabular}

Source: SPSS Calculation Version 24 
Based on the output above, it is known that the significance value (Sig.) of 0.009 is smaller than $<0.05$ probability. It can be concluded that $H_{0}$ is rejected and $H_{a}$ accepted, which means that "There is a relationship between critical and creative thinking through the Zoom application and science learning outcomes".

\section{DISCUSSION}

The researcher will explain the discussion of research that has been carried out. In this discussion, we will answer the results of problem formulation based on the research results that have been presented in the results of previous data analysis and are supported by theoretical explanations and relevant previous research.

Based on the results of data analysis of students in critical thinking through zoom meeting application on science learning outcomes, it showed very good results. Students can think critically during the learning process. It can be seen from results obtained through calculations. To find out the relationship between critical thinking (X) and learning outcomes (Y) in simple regression analysis. From the table, it is known that the significance score (Sig.) of 0.008 is smaller than the probability of 0.05 . So it can be concluded that it is rejected and accepted, which means that "There is a relationship between critical thinking and science learning outcomes". It can happen because it cannot be separated from many supporting factors during the learning process so that it can improve science learning outcomes for students.

This is in line with research from (Rahayuni, 2016) who argued that there is a relationship between critical thinking skills and scientific literacy. The relationship formed between critical thinking skills and scientific literacy is a fairly strong positive relationship. This opinion is strengthened by research (Huda \& Rahman, 2020) which said that there is a significant relationship between students' critical thinking skills so that it is necessary to empower critical thinking skills in all subjects in elementary school.

Based on the data analysis results of students in creative thinking through zoom meeting application on science learning outcomes, it showed very good results. Students can think creatively during the learning process. It can be seen from the results obtained through calculations regarding knowing the relationship between creative thinking $(\mathrm{X})$ and learning outcomes $(\mathrm{Y})$ in a simple regression analysis, it can be seen that the significance score (Sig.) of 0.006 is smaller than the probability of 0.05 so it can be 
concluded that rejected and accepted, which means that "There is a relationship between creative thinking and science learning outcomes".

It can happen because it cannot be separated from the many supporting factors during the learning process so that it can improve science learning outcomes for students. To find out the relationship between critical thinking (X $\square$ ) and creative thinking (X $\square$ ) with learning outcomes (Y) in multiple regression analysis. From the table that has been presented, it can be seen that the significance score (Sig.) of 0.009 is smaller than the probability of 0.05 . So it can be concluded that it is rejected and accepted, which means that "There is a relationship between critical and creative thinking through zoom meeting application on science learning outcomes". It can happen because it cannot be separated from the many supporting factors during the learning process so that it can improve science learning outcomes for students.

The research results above are following the researcher (Alatas, 2014) explained that in the learning process a teacher must be able to develop thinking skills and selfconcept in students so that it can lead to meaningful learning and have an impact on student learning outcomes. This research is also strengthened by previous research conducted by (Saputri, 2014) concluded that the application of the guided inquiry method can improve students' critical thinking skills and research shows that there is a relationship between critical thinking skills and student creativity and shows that if the value of students' critical thinking skills increases, student creativity also increases.

\section{CONCLUSION}

Based on the results data analysis in this study, it can be concluded that: (1) There is a relationship between critical thinking through Zoom application and science learning outcomes for the fifth grade in SD Muhammadiyah 8 Surabaya is categorized as good because the significance score (Sig.) is $0.008<$ probability $0.05 ;(2)$ There is a relationship between creative thinking through Zoom application and science learning outcomes for the fifth grade in SD Muhammadiyah 8 Surabaya categorized as good because the significance score (Sig.) of 0.006 is smaller than the probability of 0.05 ; (3) There is a relationship between critical and creative thinking through Zoom application and science learning outcomes of the fifth grade in SD Muhammadiyah 8 Surabaya categorized as good because the significance value (Sig.) is $0.009<$ probability 0.05 . 
Based on the results study, suggestions can be made that educators must be able to convey learning in a fun and meaningful way for students, besides that students, are required to be able to understand the material. In the learning process, students are asked to be active and can work together in understanding the material so that shy students do not need to ask the teacher directly unless there is an urgent problem. Therefore, critical and creative thinking is very helpful to improve student learning outcomes.

\section{REFERENCES}

Afiani, KDA, \& Faradita, MN (2021). USING THE QUIZIZZ APPLICATION TO INCREASE LEARNING OUTCOME OF PGSD STUDENTS DURING THE COVID-19 PANDEMIC. PROCEEDING UM SURABAYA, l(1).

Alatas, F. (2014). The relationship between concept understanding and critical thinking skills through the Treffinger learning model in basic physics courses. Education, 6(1), 87-96.

Antari, NLPY, Wiarta, IW, \& Putra, M. (2017). The Influence of the Two Stay Two Stray Cooperative Learning Model on Science Learning Outcomes for Class IV Ganesha University of Education. Ganesha University of Education PGSD E-Journal, 5(2), 1-10. Retrieved from http://ejournal.undiksha.ac.id/index.php/JJPGSD/article/download/10928/7004

Arikunto, S. (2010). Research Procedures: A Practical Approach. Jakarta: Rineka Cipta.

Ennis, CD (2017). Educating students for a lifetime of physical activity: Enhancing mindfulness, motivation, and meaning. Research Quarterly for Exercise and Sport, $88(3), 241-250$.

Faradita, MN (2018). Application of CLIS Learning by Using Simple Teaching Aids to Improve Problem Solving Thinking Skills.

Huda, MM, \& Rahman, L. (2020). Relationship between Critical Thinking Skills and Learning Outcomes of Elementary School Students. Journal of Character Pens (Journal of Children and Character Education), 2(2), 42-47.

Komalasari, F. (2012). The Effect of Marketing Mix on the Decision to Purchase Nokia Eseries Mobile Products. Journal of Management, (100), 1-13.

Kuntarto, E., Sofwan, M., \& Mulyani, N. (2021). Analysis of the Benefits of Using the Zoom Application in Online Learning for Teachers and Students in Elementary 
Schools. JOURNAL OF BASIC EDUCATION NUSANTARA, 7(1), 49-62.

Kusuma, AP, \& Khoirunnisa, A. (2018). Application of the Make a Match Type Cooperative Learning Model and Team Games Tournament on Learning Outcomes. NUMERICAL: Journal of Mathematics and Mathematics Education, 2(1), 1-14. https://doi.org/https://doi.org/10.25217/numerical.v2i1.186,

Neka, IK, Marhaeni, MAPAAIN, \& Suastra, MPPIW (2015). The effect of the guided inquiry learning model based on the environment on creative thinking skills and mastery of science concepts for Class V Elementary School Gugus VIII, Abang District. Ganesha University of Education.

Neolaka, YAB (2017). Development of Activated Ende Flores Natural Zeolite Adsorbent Modified By Ionic Imprinting Polymer For Cr (Vi) Analysis In. Airlangga University.

Nuruddin, M. (2018) Improving Creative Thinking Skills by Using the Mind Mapping Method in Science Education Courses for Elementary School Early Grades PGSD Students Faculty of Education Hasyim Asy'ari University ELSE (Elementary School Education Journal): Journal of Elementary School Education and Learning, 2(1), 59-77.

Putra, DA (2018). CTL-Based Learning and Inquiry to Improve Students' Critical Thinking Ability ELSE (Elementary School Education Journal): Journal of Elementary School Education and Learning, 2(2), 55-67.

Rahayuni, G. (2016) Relationship of critical thinking skills and scientific literacy in integrated science learning with PBM and STM models Journal of Science Research and Learning, 2 (2), 131-146.

Samatowa, U. (2016). Science Learning in Elementary Schools. (Bambang Sarwidji, Ed.). Jakarta: PT Index.

Saputri, NI (2014). Efforts to Improve Critical Thinking Skills for Class V Students through Guided Inquiry on Science Subjects at SDN Punukan, Wates, Kulon Progo 2013/2014 Academic Year. Thesis of Elementary School Teacher Education Study Program, Department of Pre-School and Elementary Education, Faculty of Education, Yogyakarta State University.

Sugiyono. (2019). Qualitative Quantitative Research Methods and R\&D. Bandung: Alphabeta. 
Sugiyono, S. (2016). Quantitative, Qualitative, and R\&D Research Methods. Bandung: Alphabeta.

Sulistiani, E., \& Masrukan, M. (2017). The importance of critical thinking in learning mathematics to face the challenges of MEA. In PRISMA, Proceedings of the National Mathematics Seminar (pp. 605-612).

Susanto, E., \& Retnawati, H. (2017). Mathematics learning tools with PBL characteristics to develop HOTS for high school students. Journal of Mathematics Education Research, 3(2), 189. https://doi.org/10.21831/jrpm.v3i2.10631

Wulandari, N. (2014). The effectiveness of CIRC learning with an open-ended approach to the creative thinking skills of class VIII students with cube-block material. Unnes Journal of Mathematics Education, 3(3). 